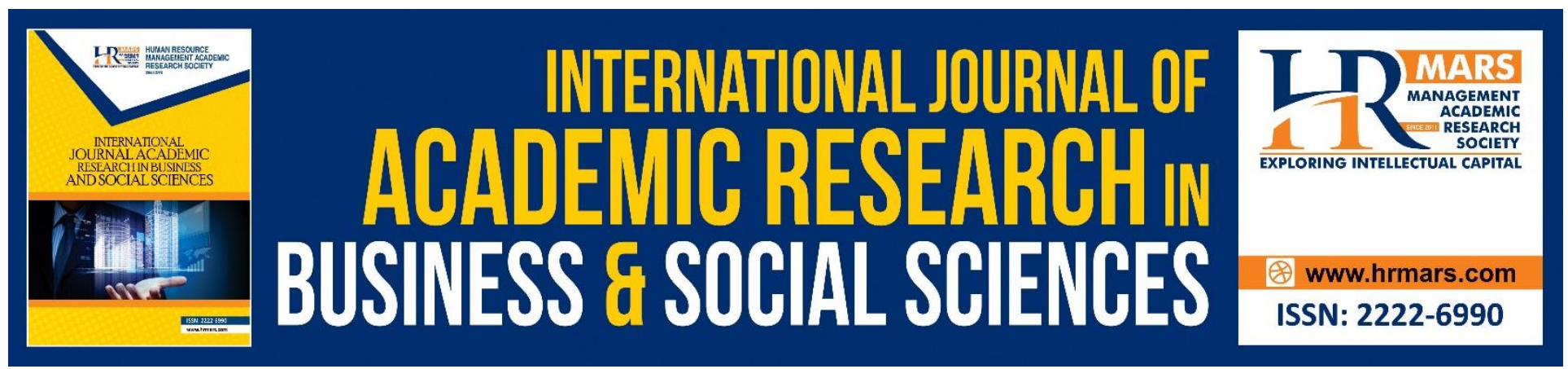

\title{
Challenges and Technologies for Affordable Housing System
}

\section{Norhasliya Mohd Daud \& Norazman Mohamad Nor}

To Link this Article: http://dx.doi.org/10.6007/IJARBSS/v8-i6/4306

DOI: $\quad 10.6007 /$ IJARBSS/v8-i6/4306

Received: 24 May 2018, Revised: 19 June 2018, Accepted: 29 June 2018

Published Online: 08 July 2018

In-Text Citation: (Daud \& Nor, 2018)

To Cite this Article: Daud, N. M., \& Nor, N. M. (2018). Challenges and Technologies for Affordable Housing System. International Journal of Academic Research in Business and Social Sciences, 8(6), 1121-1126.

Copyright: (C) 2018 The Author(s)

Published by Human Resource Management Academic Research Society (www.hrmars.com)

This article is published under the Creative Commons Attribution (CC BY 4.0) license. Anyone may reproduce, distribute, translate and create derivative works of this article (for both commercial and non-commercial purposes), subject to full attribution to the original publication and authors. The full terms of this license may be seen at: http://creativecommons.org/licences/by/4.0/legalcode

Vol. 8, No. 6, June 2018, Pg. 1121 - 1126

Full Terms \& Conditions of access and use can be found at http://hrmars.com/index.php/pages/detail/publication-ethics 


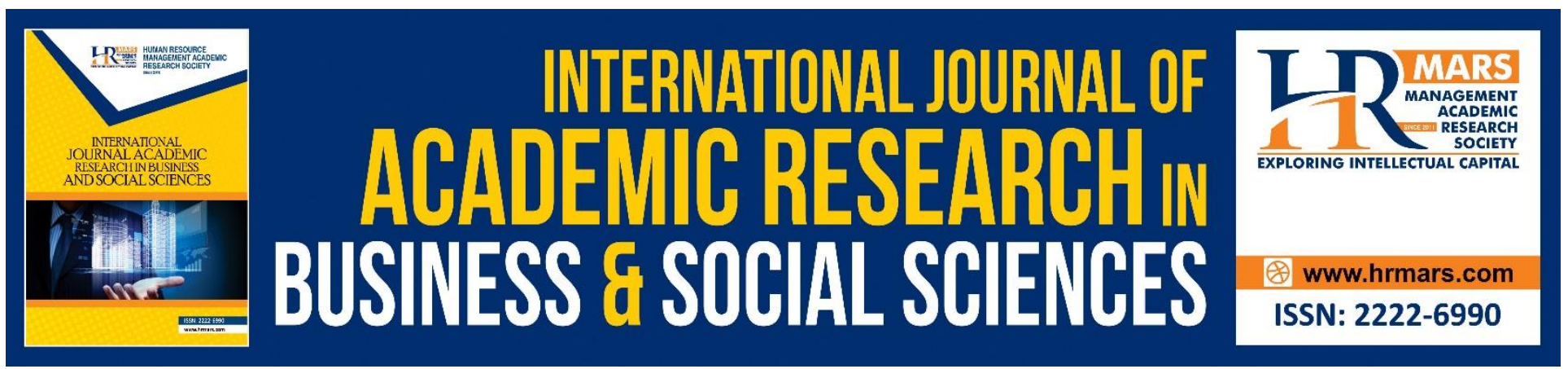

\title{
Challenges and Technologies for Affordable Housing System
}

\author{
Norhasliya Mohd Daud \& Norazman Mohamad Nor \\ Department of Civil Engineering, Faculty of Engineering, Universiti Pertahanan Nasional Malaysia,
}

\begin{abstract}
Housing affordability and provision of an adequate shelter are the challenges faced by the government in the developing countries. When the phenomenal rise in population, it resulted in shortage of dwelling units of housing especially for the low and middle income group earner. This paper aims to highlight the challenges in providing affordable houses for all. The literature analysis conducted highlighted the challenges which include high cost of construction materials and technologies, constraints on available land and high land cost, large population at the urban centers and financial constraints. The paper identifies the potential technology as a solution to deliver an affordable housing system. The finding shows that there were affordable technologies which can contribute to low cost housing which are interlocking and compressed earth block, thermal insulating technology, lightweight steel framing and bamboo reinforced wall panel. As a conclusion, the planning authorities and developers should monitor and solve the issues and challenges in providing affordable house. Using the locally available raw materials will help to reduce the construction cost. The affordable house technology may reduce the building construction costs and plays the vital role in increasing the house ownership.
\end{abstract}

Keywords: Affordable House, Housing Technologies, Affordability, Housing Issue, Housing Challenges.

\section{Introduction}

One of the major challenge in developing countries is to provide houses or shelters to satisfy the basic human needs. Government has to ensure all income levels will have access to housing ownership. Major concern is to the low and middle-income group earner because of their affordability. Their dream of owning a house is becoming difficult to realize. Isnin et al. (2012) state that it is difficult to the targeted group, low and middle-income group, to own a house due to high cost in housing prices and construction materials.

Bhangale and Mahajan (2015) define low cost housing which can be considered as affordable to low and middle income group earner if the housing unit price is not more than $30 \%$ of their household income. While Srivastava and Kumar (2018) define housing is low in cost when the society of low and median household income can afford on the housing unit. 
INTERNATIONAL JOURNAL OF ACADEMIC RESEARCH IN BUSINESS AND SOCIAL SCIENCES

Vol. 8, No. 6, June 2018, E-ISSN: 2222-6990 @ 2018 HRMARS

The objective of this study is to find out the challenges in providing affordable house for all. Further, this study reviews the affordable housing technologies used in several countries to provide affordable housing system.

\section{Affordable Housing Challenges}

One of the pressing challenges for the government is to provide adequate shelters for all. In India, they faced a shortage of houses about 17.6 million unit (Tam, 2011). Gopalan and Venkataraman (2015) state that India had shortage of 18 million houses with $99 \%$ of this is for the low-income society. Following is the discussion on some of the challenges in providing affordable housing.

I. High Cost of Construction Materials and Technologies

Ugochukwu and Chioma (2015) state that the largest input to housing construction is the building materials. This caused the target population could not afford to own a house which is beyond their affordability limit. This point also agreed by Sardroud (2012), materials itself contributed to the critical elements in building construction cost.

II. Constraints of Available Land and High Land Cost

Shortage of land for the development is caused by the high population, rapid urbanization and poorly conceived policy and regulations (Gopalan \& Venkataraman, 2015). Ugochukwu and Chioma (2015) viewed that the inaccessibility to the land caused the reduction of affordable housing provision. Scarcity of available land may contribute to the problem of high land prices, crowded neighborhoods and the squatter settlements.

III. High population at the Urban Centers

In the industrialization and urbanization era nowadays, residents from the rural area migrated to the urban centers. The migrants came to urban centers to gain a better employment (Karim, 2012). Deepak and Shanmugavelu (2014) wrote there is a big demand for housing to accommodate all people in India due to the large population. In the main cities and town, the slums and low income groups increase cause the provision of adequate housing more challenging.

IV. Income and Financial Constraints

To describe the housing affordability, housing price and income relationship is important. This factor leads to know the affordability of each person either to own or rent a house. The average income need to be addressed in order to support the debt for housing loan. Based on the examining salary of low and middle-income group, they are still facing the tight costs of living and could not own a house (Osmadi et al., 2015). Daud et al. (2017) state that the private sector should not focus only on a profit margin. They should more encourage to achieve the supply demand of affordable housing.

\section{Affordable Housing System Technology}

In order to provide an affordable housing system, it has more to do with innovations. Through a better management, appropriate use of available local materials, new skills and technology seeks to reduce the construction costs (Bhangale \& Mahajan, 2015).

I. Interlocking Block \& Compressed Earth Block

With the usage of local materials and does not require the sophisticated machine, interlocking block is quite generic, cost effective and eco-friendly (Deepak, 2012). An earthen bricks which compressed with manual hand operated or motorized hydraulic machines are called compressed earth blocks 
(CEB). CEB use the locally available materials help to improve the local economy. CEB is the suitable choice in providing the affordable house due to this type of block made of local available material and reducing the transportation cost (Sengupta 2008). Herskedal et al. (2012) state that the interlocking compressed earth blocks allow for dry stacked construction which using the cement stabilized soil blocks.

II. Thermal Insulating Technology

$\mathrm{Hu}$ and Zhu (2012) found that by using the external wall thermal insulating system, the cost of the housing is affordable and rigidly controlled. The wall body achieved the thermal insulating performance by arranging the insulating materials in the bricks. Ali et al. (2018) found that the heat resistance wall panel contributed to low interior building temperature which can minimize the usage of air-conditioning system.

III. Lightweight Steel Framing (LSF)

From Mahdavinejad et al. (2011) study, they found that LSF technology contributed to reduce the construction cost. LSF technology may emphasize on the role to supply the economic and sustainable house. This will increase the housing ownership possibility and mitigate the housing shortage crisis. LSF were built with hot rolled structural steel, integrated with wood, masonry or other conventional materials to complete the construction.

IV. Bamboo Reinforced Wall Panel

Puri et al. (2017) found that the bamboo reinforced wall panel's cost is $40 \%$ cheaper compared to the conventional 5 inches thick single wall bricks. The prefabricated bamboo reinforced wall beneficial for affordable housing. Bamboo strips were used as the reinforcement in concrete to replace the conventional method of using steel bar. Daud et al. (2018) state that by using bamboo as the building materials, the call of sustainable construction can be achieved and reduction in cost because of using readily available raw material.

\section{Conclusion}

This paper has examined the challenges to deliver adequate affordable houses. Results from the overview of the literature shows that the challenges in providing the affordable house caused by high cost of materials, land availability, high population and financial constraints, I.e. low income. To adopt the cost effective and environmental friendly housing technologies is necessary to ensure the low income group have access to own a house. The government should monitor and solve the issues and challenges to supply affordable houses. Financing facilities should be provided to the low and middleincome group to access the housing markets. Housing policy should be improved on the planning and the implementation to deliver a decent mass of affordable houses.

The paper recognizes the technologies used in several countries as the solutions to construction of affordable housing system. More usage of readily available local materials should be encouraged by the government to minimize the cost of building construction. Affordable houses can be constructed with the cost-effective building materials and construction technology.

\section{Acknowledgement}

We would like to thank the National Defence University of Malaysia and the Ministry of Higher Education, Malaysia, for sponsoring our studies. 
INTERNATIONAL JOURNAL OF ACADEMIC RESEARCH IN BUSINESS AND SOCIAL SCIENCES

Vol. 8, No. 6, June 2018, E-ISSN: 2222-6990 @ 2018 HRMARS

\section{Corresponding Authors}

Norhasliya Mohd Daud

Department of Civil Engineering

Faculty of Engineering

Universiti Pertahanan Nasional Malaysia, Malaysia.

Email: nhasliya@gmail.com

\section{References}

Ali, U.N., Nor, N.M., Yusuf, M.A., Othman, M., \& Yahya, M.A. (2018). Application of Water Flowing PVC Pipe and EPS Foam Bead as Insulation for Wall Panel, AIP Conference Proceeding International Conference on Engineering and Technology (IntCET) held on 23-24 November 2017 at the Putrajaya, Malaysia, 1930, https://doi.org/10.1063/1.5022905.

Bhangale, P.P., \& Mahajan, A.K. (2015). Cost reduction through Cost Effective Construction Techniques. International Journal of Science and Research (IJSR), 4(2), 2167-2169.

Daud, N.M., Nor, N.M., Ali, U.N., Yusof, M.A. and Munikanan, V. (2017). Affordable Housing System: A Review on Issue of Housing Affordability. The Social Sciences, 12(7), 1281-1287.

Daud, N.M., Nor, N.M., Yusof, M.A., Al Bakhri, A.A.M., \& Shaarri, A.A. (2018). The Physical and Mechanical Properties of Treated and Untreated Gigantochloa Scortechinii Bamboo. AIP Conference Proceeding International Conference on Engineering and Technology (IntCET) held on 23-24 November 2017 at the Putrajaya, Malaysia, 1930, https://doi.org/10.1063/1.5022910.

Deepak, B. (2012). Sustainable Dry Interlocking Block Masonry Construction. $15^{\text {th }}$ International Brick and Block Masonry Conference held on 15-18 Mac 2012 at the Florianopolis, Brazil.

Deepak, S., \& Shanmugavelu, V.A. (2014). Cost Effective Techniques Uses in Modern Construction Projects. International Journal of Scientific Research, 3(5), 169-170.

Gopalan, K., \& Venkataraman, M. (2015). Affordable Housing: Policy and Practice in India. IIMB Management Review, 27, 129-140.

Herskedal, N.A., Laursen, P.T., Jansen, D.C., \& Qu, B. (2012). Interlocking Compressed Earth Block Walls: Out-Of-Plane Structural Response. $15^{\text {th }}$ World Conference on Earthquake Engineering held on 24-28 September 2012 at the Lisbon, Portugal.

$\mathrm{Hu}$, X., \& Zhu, W. (2012). Analysis of Application of External Wall Thermal Insulating Technology in Affordable Housing in Tonglu Country. Energy Procedia, 14, 488-492.

Isnin, Z., Ramli, R., Hashim, A.E., \& Ali, I.M. (2012). Sustainable Issues in Low Cost Housing Alteration Projects. Procedia - Social and Behavioral Sciences, 36, 393-401.

Karim, H.A. (2012). Low Cost Housing Environment: Compromising Quality of Life?. Procedia - Social and Behavioral Sciences, 35, 44-53.

Mahdavinejad, M., Hajian, M., \& Doroodgar, A. (2011). Role of LSF Technology in Economic Housing for Urban Sustainability, Case of Iran. Procedia Engineering 2011 International Conference on Green Buildings and Sustainable Cities held on 15-16 September 2011 at the Ologna, Italy, 21, 2-7.

Osmadi, A., Kamal, E.M., Hassan, H., \& Fattah, H.A. (2015). Exploring the Elements of Housing Price in Malaysia, Asian Social Science, 11(24), 26-38.

Puri, V., Chakrabortty, P., Anand, S., \& Majumdar, S. (2017). Bamboo Reinforced Prefabricated Wall Panels for Low Cost Housing. Journal of Building Engineering, 9, 52-59. 
INTERNATIONAL JOURNAL OF ACADEMIC RESEARCH IN BUSINESS AND SOCIAL SCIENCES

Vol. 8, No. 6, June 2018, E-ISSN: 2222-6990 @ 2018 HRMARS

Sardroud, J.M. (2012). Influence of RFID Technology on Automated Management of Construction Materials and Components. Scientia Iranica, 19(3), 381-392.

Sengupta, N. (2008). Use of Cost-effective Construction Technologies in India to Mitigate Climate Change. Current Science, 94(1), 38-43.

Srivastava, M. \& Kumar, V. (2018). The Methods of Using Low Cost Housing Techniques in India. Journal of Building Engineering, 15, 102-108.

Tam, V.W.Y. (2011). Cost Effectiveness of Using Low Cost Housing Technologies in Construction. Procedia Engineering The Twelfth East Asia-Pasific Conference on Structural Engineering and Construction held on 26-28 January 2011 at the Hong Kong, China, 14, 156-160.

Ugochukwu, I.B. \& Chioma, I.B. (2015). Local Building Materials Affordable Strategy for Housing the Urban Poor in Nigeria. Procedia Engineering International Conference on Sustainable Design, Engineering and Construction held on 10-13 May 2015 at the Chicago, USA, 118, 42-49. 